\title{
SEPÉ - O MORUBIXABA REBELDE (1964), UM ÉPICO MODERNO ${ }^{1,2,3}$
}

\section{SEPÉ - MORUBIXABA REBELDE (1964), A MODERN EPIC}

\section{Ellen dos Santos Oliveira"}

Resumo: Esse trabalho tem como objetivo analisar a o poema épico moderno Sepé - o morubixaba rebelde (1964), de Nilo Fernandes Barbosa, à luz de uma fundamentação crítica teórica atualizada do Gênero épico, a fim de compreender como essa manifestação do discurso épico está representada na Modernidade, através desse poema que se configura como um registro da permanência do gênero nas nossas Letras. Assim, como apoio teórico metodológico, usaremos as contribuições dos críticos teóricos do CIMEP, entre eles: Anazildo (1984), Ramalho e Silva (2007; 2015), Silva (2012), Ramalho (2004, 2013; 2017), Neiva (2009; 2012), Mesa Gancebo (2009), entre outros. Pretende-se com essa análise contribui com a fortuna crítica sobre o autor, sobre o gênero épico, e sobre a literatura brasileira.

Palavras - chave: Gênero épico; Sepé - o morubixaba rebelde; Fernandes Barbosa (19101988).

AвSTRACT: The objective of this work is to analyze the modern epic poem Sepe - the rebelde morubixaba(1964), by Nilo Fernandes Barbosa, in the light of an updated theoretical critical foundation of the epic genre, in order to understand how this manifestation of epic discourse is represented in Modernity, through this poem that is configured as a record of the permanence of the genre in our Letters. Thus, as theoretical methodological support, we will use the contributions of the theoretical critics of CIMEP, among them: Anazildo (1984), Ramalho e Silva (2007, 2015), Silva (2012), Ramalho (2004, 2013, 2017), Neiva (2009,2012), Mesa Gancebo (2009), among others. It intends with this analysis contributes with the critical fortune on the author, on the epic genre, and on Brazilian literature.

KEY words: Epic genre; Sepé - the rebelde morubixaba; Fernandes Barbosa (1910-1988).

\footnotetext{
${ }^{1}$ Este trabalho, com alguns ajustes, é parte da minha Dissertação de Mestrado "O herói Sepé em duas versões: O Uraguai e Sepé - o morubixaba rebelde". A obra Sepé - o morubixaba rebelde compõe o corpus literário da minha pesquisa de tese de doutorado, em desenvolvimento com o apoio da Capes, com o título: Jesus Cristo no Epos da Nação: a intertextualidade bíblica na obra épica de Fernandes Barbosa.

${ }^{2}$ Pesquisa desenvolvida sob a orientação da profa. Dra. Christina Ramalho (UFS/CIMEEP)

${ }^{3}$ O presente trabalho foi realizado com apoio da Coordenação de Aperfeiçoamento de Pessoal de Nível Superior - Brasil (CAPES) - Código de Financiamento 001.

"Doutoranda em Letras pela Universidade Federal de Sergipe (UFS). Email: profa.ellen.oliveira@live.com. Orcid: https://orcid.org/0000-0002-4728-5766.
} 


\section{INTRODUÇÃo}

Este trabalho parte de Sepé Tiaraju. Líder indígena que lutou até a morte na disputa pela terra, herança de seu povo, na guerra guaranítica contra os portugueses e espanhóis nas Missões Jesuíticas nos Sete Povos das Missões, no Rio Grande do Sul. Segundo Lopes Neto (1998), José Tiaraju, conhecido por Sepé Tiaraju, após sua morte três dias antes da batalha de Caibaté, em 07 de fevereiro de 1756, foi homenageado pelos jesuítas que batizaram o Arroio onde à margem existia a sepultura do índio de "Arroio São Sepé", indicado por uma cruz de madeira, e com a inscrição:

Em nome de todos os Santos

No ano de Cristo Jesus de 1756

A 7 de fevereiro

morreu combatendo

O grande chefe guarani Tiarajú

em um sábado santo

Subiu ao Céu dias antes que

o grande chefe da Taba do Uruguai

que morreu a 10 de fevereiro em quarta-

feira combatendo contra um exército

de 15.000 soldados.

Aqui enterrado

A 4 de março

mandou levantar-lhe esta cruz

o padre D. Miguel

Descansa em paz

(LOPES NETO, 1998, p. 227-228)

Embora não seja considerado Santo pela Igreja Católica, a partir dessa homenagem prestada pelos jesuítas, Sepé Tiaraju passa a ser conhecido e reconhecido como o santo popular São Sepé. Nome atribuído a um município no Rio Grande do Sul.

Também famoso, sob a ótica da herança literária deixada por Basílio da Gama, em $O$ Uraguai (1769), mas, tal como aponta Bakhtin (1981), uma figura emblemática de um universo histórico, mítico e cultural que ultrapassa o âmbito dessa herança, ganhando independência tal que lhe permite circular por manifestações históricas, artísticas e literárias diversas. Uma dessas manifestações é Sepé, o morubixaba rebelde (1964), de Fernandes Barbosa, que integra um grupo de produções literárias que tem como propósito a contação a (re) contação da história do índio Sepé Tiaraju, já que por 144 anos a única versão literária conhecida era a de Gama. 
Essas obras são O lunar de Sepé (1913), poema de Simões Lopes Neto, Tiaraju (1945), romance histórico de Manoellito de Ornella, O continente (1949), romance de Érico Veríssimo, Sepé-o morubixaba rebelde (1964), poema épico de Fernandes Barbosa, e Sepé Tiaraju-romance dos Sete Povos da Missão (1975), romance de Alcy Cheuiche, cuja versão é adaptada para histórias em quadrinhos. Nota-se, com tais produções, um movimento divisor de águas que abre caminhos para uma vasta produção artística cultural de reconhecimento e reafirmação do heroísmo do índio. Tanto que esse reconhecimento da atuação, da bravura e da coragem de Sepé Tiaraju é legalizado por lei $\mathrm{n}^{\circ} 12.032$, de 21 de setembro de 2009 , que determina:

O VICE - PRESIDENTE DA REPÚBLICA, no exercício do cargo de PRESIDENTE DA REPÚBLICA Faço saber que o Congresso Nacional decreta e eu sanciono a seguinte Lei:

Art. 10 Em comemoração aos 250 (duzentos e cinquenta) anos da morte de Sepé Tiaraju, será inscrito no Livro dos Heróis da Pátria, que se encontra no Panteão da Liberdade e da Democracia, o nome de José Tiaraju, o Sepé Tiaraju, herói guarani missioneiro rio-grandense (PRESIDÊNCIA DA REPÚBLICA, 2009) ${ }^{4}$.

Das obras citadas acima, Sepé - o morubixaba rebelde (1964) chama atenção, não só pela qualidade estética da obra que apresentam inovações dentro da concepção de épico moderno, mas, também, pelo fato de seu autor, Fernandes Barbosa, acusar Basílio da Gama de, em O Uraguai, "falsear a verdade histórica do herói indígena”.

José Basílio da Gama, poeta mineiro, e primeiro pelego nacional, desejando favores da Côrte, através, do ministro Sebastião José de Carvalho, escreveu o poema "O Uraguai”, enaltecendo Gomes Freire e José Joaquim Viana, falseando, subalternamente, a verdade histórica, em detrimento de Sepé Tiaraju (sic. FERNANDES BARBOSA, 1964, p. 83)

Um dos leitores de Fernando Barbosa, Bras Camilo, ao ler o Sepé - o morubixaba rebelde, fez a seguinte crítica no Jornal:

Falando em história, ao ler Sepé - o Morubixaba Rebelde, confesso que tive uma decepção. Admirava o lírico José Basílio da Gama, da Marfiza cruel, como o mais lírico dos poetas líricos do Brasil. Não conhecia o poema de sua autoria "Uraguai", no qual, torcendo e falseando a verdade, enaltece, em troca de favores, a Gomes Freire e José Joaquim Viana, em detrimento de Sepé Tiaraju. Mais de duzentos anos são passados e Fernandes Barbosa aponta-o agora como o primeiro pelego nacional. Bem feito. (BRAS CAMILO, In. Jornal do Povo,1964).

${ }^{4}$ Disponível em: < http://www.meuvademecumonline.com.br/legislacao/leis_ordinarias/763/pagina_1/7/12-032-de-21-92009/> Último acesso em dez. de 2015. 
Assim, o poeta contestador irá recontar a história do herói e, baseado em uma pesquisa histórica, agirá em defesa do índio, narrando em seus versos uma nova versão de Sepé Tiaraju. Do confronto entre as duas obras e das considerações sobre diversas implicações envolvidas no repertório cultural associado à figura de Sepé, transitaremos, aqui, pelo universo épico desse herói brasileiro.

No entanto, ficam duas perguntas iniciais: Fernandes Barbosa!? Quem foi esse poeta que, ao escrever Sepé - o morubixaba rebelde, ousou afirmar que Basílio da Gama, autor do reconhecido épico O Uraguai, falseou, subalternamente, a verdade histórica do índio herói Sepé Tiaraju dando-lhes ao público leitor uma versão maquiada e sob a ótica do colonizador?

Como poeta e mísero escriba, sou um anacoreta metido na selva de pedra de uma cidade, a pensar num mundo sem fronteiras, inteiramente diferente das tricas e lutas da vida estúpida do dinheiro. Um mundo onde os homens não se digladiassem por pedaços de terra. Não impusessem uns aos outros sistemas de vida, pela força. Um mundo onde as crianças, sem distinção de raças e de cores, pudessem brincar à sombra benfazeja da mesma bandeira, sem a eterna apreensão de serem esmagadas pelas patas dos quatro cavalheiros do Apocalipse, que se escondem nas estrebarias dos arsenais (FERNANDES BARBOSA, In. Jornal do Povo, 1981).

Para o cenário das letras brasileiras, Fernandes Barbosa deixou uma vasta produção literária. Durante a minha ida à Cachoeira do Sul - RS, para fins de pesquisa, consegui reunir: 14 livros - Frutinha proibida (1938), Minhas flores de Jacarandá (1944), Os 'gatos' e o remédio (1949), Carreirada (1954), Figurinhas do Bazar (1956), Noite Feliz (1958), Súplica ao Negrinho do Pastoreio (1959), Cretino é quem toma de uma enxada (1960), Sepé - o morubixaba rebelde (1964), Para aonde marcha o Brasil? (1978), Tradição Relambória (1984), Preto e branco (1986), Trovas ao vento (1986), Esbôço de uma época (1987); quatro contos - "A alma do pai tá de acordo?..." "Crime e sentença”, "Tirada de castelhano", e "O preço de um pecado"; crônicas - "Flor agreste brotada na pedra", "O engolidor de caminhos", além de mais de uma centena de poemas espessos e inéditos, datilografados e manuscritos.

\section{SEPÉ- O MORUBIXABA REBELDE (1964) E A MATRIZ ÉPICA MODERNA}

O poema épico Sepé - o morubixaba rebelde, de Fernandes Barbosa, publicado em 1964, integra a matriz épica moderna. Quando a concebeu o poeta se incluiu no grupo de artistas e intelectuais modernistas que estavam mais voltados para o tradicionalismo, a geração de 45 ou neoparnasiana.

Conforme explica Anazildo Silva (2012), o que caracteriza a épica moderna é a elaboração literária da matéria épica, não que este caráter se restrinja apenas a essa matriz, pois 
temos o exemplo da obra Guesa de Sousândrade, do século XX, pré-moderno, em que ele pega a estrutura mítica do Guesa, a estrutura mítica, um mito pré-colombiano, e a usa na concepção de Jung, como um arquétipo, para a representação histórica da colonização dos povos americanos (SILVA, 2012).

Trata-se de uma obra que faz refundir, na nova imagem de mundo da Modernidade, os referenciais históricos e simbólicos representados na épica clássica O Uraguai, na tentativa de resgatar e renovar o mito do herói Sepé Tiaraju, através da intervenção criadora da elaboração literária moderna, expandindo a aderência mítica desse herói, e reescrevendo os acontecimentos heroicos narrados no passado, na épica basiliana, contextualizando com a história contada no presente. Assim, fundem-se o presente e o passado, através da atemporalidade mítica, que acaba integrando um novo poema épico. Segundo Vasconcelos Silva (2007) as características do modelo épico moderno são:

A elaboração literária da matéria épica; a estrutura mítica como forma de representação histórica; o centramento do relato no plano literário; participação plena do eu-lírico/narrador no mundo narrado; dimensão temporal do presente unitário; uso da $1^{\mathrm{a}}$ pessoa integrando o herói na instância de enunciação do eu-lírico/narrador; a construção de uma identidade heróica referencial que institui o herói metonímico; o recurso lírico da auto-referenciação e o narrativo da auto-contextualização; o diálogo intertextual; o encadeamento atemporal dos fatos históricos e a total liberdade rímica, métrica e estrófica (SILVA, 2007, p. 141).

Em Sepé - o morubixaba rebelde percebe-se uma elaboração literária da matéria épica, com feição mais moderna e já mais livre em relação à estrutura de uma obra épica clássica da literatura ocidental. O poema tem a estrutura mítica como forma de representação histórica do herói Sepé Tiaraju, centrando o relato no plano literário da obra. Nota-se também a participação plena do eu-lírico/narrador no mundo narrado, tamanha é a intimidade do poeta com o personagem heroico, o que vincula a obra ao presente temporal. É frequente o uso da $I^{a}$ pessoa, integrando o herói na instância de enunciação do eu-lírico/narrador, que se auto-identifica com o herói e o trata com evidente aproximação.

\section{A estrutura épica de Sepé, o morubixaba REBELDE}

Fernandes Barbosa ao escrever Sepé - o morubixaba rebelde assume a intenção épica, construindo o poema com os elementos de uma epopeia clássica, embora numa elaboração bem moderna, e construindo literariamente a matéria épica, fundindo referenciais históricos, que se referem a atuação heroica do índio Sepé Tiaraju durante a execução do tratado de Madri que culminou na guerra guaranítica, e com referenciais simbólicos do agenciamento desse herói no espaço mítico elaborado. Não há dúvidas de que o herói do poema é Sepé Tiaraju. Ele é o sujeito principal da narrativa, o ser mítico, que transita entre o plano histórico e maravilhoso. 
O poema épico é composto por oito cantos, 818 versos decassílabos e distribuídos em sextilhas. Diferente de O Uraguai (1769), em que os cantos não são intitulados, o que é normal na tradição épica, no poema de Fernandes Barbosa os cantos são todos intitulados conforme os episódios do enredo, e essa já é uma estrutura moderna de épico. Assim: Canto I - Sepé e o berço natal; Canto II - O tratado de Madri; Canto III - A entrevista do pala com os bordados; Canto IV - O pacto com Gomes Freire, e a discordância de Valdelírios e a ingênua credulidade dos índios; Canto V -A invasão do território guarani; Canto VII - A batalha de Caibaté; Canto VIII - Ao vencedor, as batatas!.

$\mathrm{Na}$ abertura do poema é possível identificar a invocação patriótica, pois o poeta direciona seu fazer poético à cidade do Rio Grande, e isso demonstra o desejo de exaltar o heroísmo do guerreiro Sepé para que este venha a ser reconhecido, não só entre os gaúchos, mas também nacionalmente.

O poema traz uma invocação convocatória, ao entregar seus versos às mãos dos índios pampeanos, originados dos pampas, região da campanha no Rio Grande do Sul. São os "índios crus", uma vez que o autor se propõe a retratá-los sem idealizações, que o poeta convoca para participar da matéria épica e/ou julgar seu poema, já que estes estão esboçados no poema como um retrato. Assim o eu-lírico/narrador chama o destinatário pátrio para construção de seus versos. Conforme se vê na invocação, o poeta desloca o eixo de produção, centrado na primeira estrofe, para o da recepção, na segunda estrofe, na qual destinatários estão presentificados, criando, assim, um efeito retórico de aproximação entre o escritor, obra e leitor.

No azinhavrado vinte réis de cobre,

Da rima tosca do meu canto pobre,

- Pois não nasci um vate-uirapuru -

Se pús, Rio Grande, o teu Sepé no verso,

Cunhei a efígie, pelo seu reverso,

Do grande taita que foi Languiru.

O meu vintém sem nenhum ornato,

Que ponho agora, ás mãos dos índios crus,

Apenas traz o esboço do retrato,

Do pampeano perfil dos dois xirus.

(FERNANDES BARBOSA, 1964, p. 8)

A invocação mescla a linguagem entre a indígena e a regional, a qual o poeta demonstra dominar muito bem. Quando diz "no azinhavrado vinte réis de cobre", o poeta refere-se a algo que já está ultrapassado, a moeda que traz estampada a face heroica de Sepé já está ultrapassada. Ao dizer, modestamente, "rima tosca" de seu "canto pobre", o poeta refere-se ao metro 
que utiliza para cantar o herói que é a sextilha decassílaba em rimas (AABCCB) que é o metro tipicamente popular utilizado desde os cancioneiros medievais e que é a sua preferência, pois não nasceu um "vate-uirapuru", ou seja, um poeta de canto melodioso e encantador que cunhou a "Efígie" - significa a representação real ou simbólica de uma pessoa ou divindade de Sepé, pelo seu "reverso" - lado oposto ao principal - "do grande taita" - valentão, corajoso - que foi Nicolau "Languiru”, o sucessor de Sepé Tiaraju após sua morte, que não chega a ser mencionado em O Uraguai, que narra que quem comandou os índios foi Cacambo (outro fato apontado como falso). Na segunda estrofe, o eu-lírico/narrador diz que seu "vintém sem o menor ornato", ou seja, seu canto sem enfeites, e colocado "às mãos dos índios crus" para ser "esboço do retrato" do "pampeano perfil dos dois xirus", a saber o esboço do retrato desses dois velhos companheiros, Sepé Tiaraju e Nicolau Languiru. Nota-se na invocação não há menção a Cacambo, que só será citado no início do poema, deixando evidente que ele não era o chefe da taba, conforme insinua o épico de Gama.

Sepé - o morubixaba rebelde apresenta uma proposição referencial nomeada em forma de poema, integrada no Canto I, (RAMALHO, 2013) "Sepé e o berço natal", em que o poeta apresenta uma síntese do que se tratará no poema. Quanto ao centramento temático, a proposição está focada na figura do herói que é o guerreiro Sepé Tiaraju nos Sete Povos da Missão. Conforme se pode observar:

Na terra boa e fértil que era tua, Aperfeiçoando o arado da charrua, Para o labor das lutas pastoris, $\mathrm{Tu}$ - índio macho, Tiaraju valente Fôste o supremo Chefe desta gente, Dos guapos, indomáveis, guaranis.

Ao lado de Cacambo, Caitetu, Pindó, Lindóia e Tatu-Guaçu

- Que nunca desonraram teus brasões -

$\mathrm{Tu}$ - meu Sepé, herói Morubixaba -

Não foste, apenas, Chefe de uma taba,

Foste o fanal divino das Missões.

(FERNANDES BARBOSA, 1964, p.10)

Nota-se que aí, na proposição, já aparece Cacambo sutilmente colocado de princípio "ao lado de Caitetu, Pindó, Lindóia e Tatu-Guaçu”, ou seja, Cacambo será retratado como os outros índios valentes que lutaram ao lado de Sepé, e não como o chefe da taba, nem o herói épico como em O Uraguai. 
O poeta contestador deixa bem claro que Sepé Tiaraju "Não foste, apenas, Chefe de uma taba", mas "o fanal divino das Missões", dando a ele desde início o lugar que é seu por história e, portanto, por direito. Assim, Fernandes Barbosa, no processo de criação, opta por focar a proposição na imagem do herói, e deixa evidente a sua intenção de reescrita da história do índio.

Em relação ao plano maravilhoso, Fernandes Barbosa retoma a imagem mítica do índio Sepé Tiaraju, o guerreiro lunar. A inserção do personagem mítico no plano maravilhoso ocorre no Canto VI - "O Lançaço às costas do Rio Grande", quando o lunar de Sepé misteriosamente aparece no céu após a morte do índio. Esse momento está retratado no fragmento abaixo:

Dobram os sinos pelo filho morto,

Envolve-se as Missões no desconforto,

O luto cobre as almas sofredoras!

Da sua oposição ruíram-se as comportas,

Os Sete Povos já não têm mais portas,

Podem entrar as tropas invasoras.

Enquanto à noite o povo se estarrece,

De joelhos cai, chorando numa prece,

E logo a causa toda se advinha:

No manto azul do céu todo estrelado,

Pela primeira vez se vê gravado,

Um cruzeiro de estrelas que não tinha.

(FERNANDES BARBOSA, 1964, p. 97-108)

Sobre esse aspecto falaremos no próximo tópico de forma mais comparativa, mas adianta-se aqui que, em nota de rodapé, Fernandes, ao explicar o significado de "um cruzeiro de estrelas", diz que "Era o lunar que Sepé trazia à testa e que, segundo a lenda, no 'céu tomou posição". Ou seja, o poeta utiliza uma fonte mítica tradicional, uma vez que a imagem mítica foi extraída da tradição cultural. Sobre esse aspecto, Ramalho (2013) comenta que:

A figura do índio Sepé constitui um exemplo de imagem mítica diretamente captada da cultura - no caso a rio-grandense brasileira. Explorada também por outros escritores, como Alcy Cheuíche, por exemplo a imagem mítica de Sepé (tal como outras que integram o repertório cultural brasileiro) oferece-se portanto, como matéria épica. (RAMALHO, 2013, p. 124).

Em relação ao plano literário, percebe-se que o poeta, além de utilizar a estrutura de uma epopeia clássica, já aqui mencionado, é dotado de maior liberdade de criação na construção do 
herói co-relacional, valendo-se dos recursos de transcendência textuais, como: intertextualidade, paratextualidade, arquitextualidade, metatextualidade e hipertextualidade.

Logo no primeiro Canto do poema, ao apresentar o herói Sepé Tiaraju, o poeta utiliza marcas intratextuais para caracterizar o herói, ou seja ele associa Sepé a vários outros herói famosos da tradição cultural: Deus, "São Miguel intrépido bagual”/ "fôrça hercúlea sobrenatural"/ "Herdeiro da nobreza dos entanhos" (p.12), "Como Moisés”(p.21), “altivez augusta” (p.35) e até "demônio" (p.58). Essa forma de superpor vários heróis na instância épica de representação do herói caracteriza a construção do herói correlacional.

Ainda no que diz respeito ao plano literário, o poeta recorre a vários paratextos para explicar os pretextos de seu poema e de sua exaltação a Sepé Tiaraju. Assim, os paratextos compõe a obra como um todo e servem como suporte para conduzir o leitor a uma compreensão mais profunda da história de Sepé, pois, para criá-lo está evidente que o poeta se aprofundou na história para poder contestá-la ao dialogar com O Uraguai de Basílio da Gama. Esses paratextos são os acessórios que compõem a obra como um todo: o título e subtítulo, o prefácio, legenda, ilustração e as notas de rodapé. Esses textos, que se posicionam além do poema, foram deixados, pelo poeta, à disposição do leitor para auxiliá-lo no seu entendimento da criação literária em si.

O título e subtítulo do poema de Fernandes Barbosa fornecem uma pista do assunto do qual tratará a obra. O título leva o nome do herói épico Sepé, e a partir dessa percepção o leitor é conduzido a uma compreensão de que o poema tem como foco principal a história do herói que integra a história cultural do povo do Rio Grande do Sul, e que foi representada na obra O Uraguai de Basílio da Gama. O subtítulo também é um tópico importante, pois ele sintetiza a forma como o poeta pretende cantar o índio em seus versos, ou seja, como um "morubixaba rebelde" e não como um índio idealizado à la Rousseau. Ou seja, Sepé o chefe dos índios que comandou a primeira rebelião nacional.

O poema Sepé - o morubixaba rebelde (1964) tem o respaldo de dois grandes conhecedores da história de Sepé Tiaraju: o escritor e historiador Manoelito de Ornellas, que escreveu o romance histórico Tiaraju, e prefaciou, sob o título de "Pórtico"s, o poema de Fernandes Barbosa; e o historiador Walter Spalding, que, escreveu o "Conversa desnecessária” ${ }^{6}$, também prefácio do poema.

"Conversa desnecessária" realça o desejo, a pretensão, de que, através do poema, o heroísmo de Sepé Tiaraju seja reconhecido. Walter Spalding aponta uma necessidade de consagração do heroísmo de Sepé Tiaraju na Literatura Brasileira, necessidade que, conforme suas palavras, parece ser suprida pela criação do épico de Fernandes Barbosa. E isso conduz a interpretar que, apesar de que o índio já havia sido retratado, em tom épico, em O Uraguai

\footnotetext{
${ }^{5}$ Ver Anexo A - Cópia do manuscrito do prefácio de Sepé - o morubixaba rebelde, intitulado "Pórtico" feito pelo escritor e historiador Manoelito de Ornellas.

${ }^{6}$ Ver Anexo B - cópia do manuscrito do prefácio de Sepé - o morubixaba rebelde, intitulado “Conversa Desnecessária” feito pelo historiador Walter Spalding.
} 
por Basílio da Gama, o índio ainda não havia sido reconhecido e consagrado como deveria, ao ver dos críticos gaúchos. Como se pode ver em anexo, para Walter o poema está longe de ser considerado uma produção épica qualquer, mas uma "joia literária", um "marco na literatura", uma vez que cultuará, acima de tudo, a verdade histórica atribuindo ao índio seu verdadeiro valor histórico, social e cultural.

Os comentários críticos de Walter Spalding que integram o prefácio da obra, além de constituírem um paratexto também estabelecem uma relação de metatextualidade, que consiste em um comentário crítico sobre o poema. Tal recurso conduz o leitor a um posicionamento crítico direcionado em relação ao poema e ao heroísmo épico que será tratado.

Ao finalizar o texto de apresentação do poema, Fernandes Barbosa, deixa uma legenda que expressa bem a intenção de problematizar a ideia de verdade histórica do heroísmo indígena, quando afirma: "SOBRE O CORPO BRONZEADO DA VERDADE HISTÓRICA / O PALA ESFARRAPADO DO MEU VERSO".

Outro elemento paratextual que merece comentário é a ilustração impressa antes dos versos de invocação que antecedem o poema. Trata-se de uma moeda que leva a imagem do herói Sepé Tiaraju desenhada, o que deixa mais evidente a intenção em construir um real sentido que valorize a história do herói, uma vez que Fernandes Barbosa parece acreditar que nos versos basilianos a imagem que mais parece ser valorizada é a do General Gomes Freire de Andrade, e não a do índio herói, ao menos não como merecia ser valorizada. Por esse motivo, o poeta lança mão de vários recursos para realçar o sentido de valorização indígena e cultural que ele pretende exaltar em seus versos.

Outros paratextos que contêm uma importante função pragmática para a compreensão e interpretação do poema épico são as notas de rodapés, que, por sinal, não são poucas, se considerarmos que o poema épico Sepé - o morubixaba rebelde foi editado com 83 páginas, com 8 cantos, sendo que cada os sete primeiros contém duas estrofes de seis versos, e o último canto é um soneto. Nessa composição Fernandes Barbosa escreve 46 notas de rodapé, um número significativo considerando a proporção do poema épico, mostrando um vínculo com a tradição épica clássica, cujos recursos paratextuais eram comuns.

Tabela 1: Análise dos paratextos

\begin{tabular}{c|c}
\hline FUNÇÃO DA NOTA DE RODAPÉ & $N^{\circ}$ DA NOTA DE RODAPÉ \\
\hline Explicação histórica & $\begin{array}{r}1,2,3,4,5,6,7,8,9,10,11,12,13,14,15,18,19,20,21,22,23, \\
24,27,28,29,32,33,34,35,36,37,40,41,43,45,46 .\end{array}$ \\
\hline Explicação geográfica & $4,21,25,31,38$. \\
\hline Explicação linguística & $16,17$. \\
\hline Explicação sobre personagens & $1,6,8,10,11,12,23,26,27,28,32,37,39,40,41,42,43,45$. \\
\hline Explicação sobre o enredo & $9,14,15,20,22,28,30,36,41,42$. \\
\hline Explicação sobre lendas & 42. \\
\hline
\end{tabular}


Apesar de ser um recurso natural do gênero épico, as notas de rodapé no épico de Fernandes Barbosa são fundamentais para uma compreensão mais acurada das revisitações históricas feitas pelo poeta, e justificam não só o plano histórico, mas também o literário e maravilhoso. Nessas explicações o poeta comenta, critica, explica e imprime suas impressões sobre a obra que cria, e paralelamente sobre a obra de Basílio da Gama, O Uraguai, com a qual Fernandes acaba estabelecendo um diálogo intertextual, enquanto dialoga, e hipertextual, no exercício de reescrita.

No paratexto, ou texto de apresentação da obra, intitulado "Antes do Nada", Fernandes Barbosa deixa evidenciada a predominância da história em seus versos. Percebe-se nisso uma preocupação em buscar, resgatar e valorizar, na memória coletiva do povo gaúcho a imagem mítica do herói Sepé Tiaraju, quando ele diz:

O modesto trabalho que hoje incorporo às letras xucras do pago, entregando-o à curiosidade do público ledor, talvez - aos olhos dos leigos - possa desfilar como um poema épico, adornado de flores da poesia agreste, e através do qual - enaltecendo a altivez e o espírito rebelde da nossa gente, sempre inamolgável aos desmandos e à prepotência domadores estranhos ao nosso chão - procuro, acima de tudo, dar simbolismo nativo à figura inconfundível de Sepé Tiaraju, cada vez mais redivivo, no coração intimorato do Rio Grande (FERNANDES BARBOSA, 1964, p. 07).

Adiante ele diz:

Mas, a visão panorâmica e versátil dos entendidos, à experiência analítica dos críticos exigentes, eternos esvurmadores de claudicâncias literárias, acredito que não passe despercebido a falha involuntária em que incidi, permitindo, em algumas passagens, uma certa predominância da história sobre a poesia (BARBOSA, 1964, p. 07).

Percebe-se o caráter auto/ reflexivo do autor em relação à sua escrita literária, e especificamente ao texto histórico que ele utiliza para confirmar sua escrita. Ao mesmo tempo o autor, questiona a própria história da Guerra Guaranítica, o lugar do herói Sepé Tiaraju nessa história e como ela foi contada por Basílio da Gama na obra O Uraguai.

Se tal acontecer - e forçosamente acontecerá - eu me curvarei à evidência dos fatos, explicando que não vacilei em sacrificar a poesia em benefício da história, admitindo, em verdade, em várias sextilhas, que esta sobrepujasse àquela, sem prejudicar o verde-amarelismo da essência que, no caso, é SEPÈ - paradigma do caudilhismo dirigente, fruto e semente, raíz, planta e flor da primitiva terra do Rio Grande! (FERNANDES BARBOSA, 1964, p. 07). 
Percebe-se que o poeta acaba assumindo, nesse contexto, aquilo que seria a tarefa do historiador, e conforme diz Gagnebin tal tarefa se dá a partir da necessidade de lutar contra o esquecimento e a denegação, lutar contra a mentira, mas sem cair em uma definição dogmática de verdade (GAGNEBIN, 2006, p. 44). Fernandes Barbosa tentará mostrar em seu poema a verdade histórica sob sua ótica moderna e atualizada dos fatos históricos.

Essa concepção de historiografia semelhante à que Gobbi fala ser a de Hegel, ou seja, aquela capaz de, através da linguagem, tentar "dar conta" do real. E isso acaba confundindo, de certa forma, os limites entre linguagem e realidade (GOBBI, 2004, p. 42), e no caso do poema, a relação dialógica entre história e ficção.

Fernandes Barbosa, ao classificar sua produção literária como um poema, e deixar essa taxonomia explícita na capa de sua obra, deixa o leitor ciente da identificação genérica de sua criação literária. Assim, o leitor, em primeira instância, ao se deparar com tal classificação tem uma noção, antes mesmo de começar a folhear a obra, que está diante de um poema, e não um livro de história, romance, um ensaio, etc. E, como diz Genette (2010), essa classificação é importante, pois a percepção do gênero em larga medida orienta e determina o horizonte de expectativa do leitor e, portanto, da leitura da obra (GENETTE, 2010, p. 17).

Partindo do conceito de hipertextualidade batizado por Genette (2010) entende-se por hipertexto toda relação que une um texto B, hipertexto, a um texto anterior A, hipotexto, Sepé, o morubixaba rebelde, além de conter as transcendências textuais já comentadas aqui, será classificado como um hipertexto. Sepé - o morubixaba rebelde de Fernandes Barbosa é o texto B, e O Uraguai de Basílio da Gama é o texto A, ou seja, a primeira versão.

Para tal consideração, é só pensar a noção de texto de segunda mão ou texto derivado de outro texto preexistente, e na relação em que o texto $B$ fale de $A$, e também cuja existência de $B$ dependa da existência de $\mathrm{A}$. E isso não implica na qualidade literária de ambos, até porque, como explica Genette (2010), a hipertextualidade é uma característica universal evidente da literariedade, ou seja, ser hipertextual é um caráter próprio da obra literária. Claro que algumas são mais hipertextuais que outras, dependendo do grau e leituras em que é perceptível que algumas obras evoquem outras, logo todas as obras literárias são hipertextuais (GENETTE, 2010, p. 24).

A percepção da intertextualidade vai depender da atividade hermenêutica do leitor. No poema de Fernandes Barbosa, não há dificuldades para perceber essa relação que a obra estabelece com o poema épico O Uraguai, pois a sua intenção hipertextual está evidentemente declarada em seus paratextos, arquitextos, metatextos, e intertextos. 


\section{SOBRE O HEROÍSMO ÉPICO}

Em relação ao heroísmo épico, a obra de Fernandes Barbosa adianta algumas características do épico pós-moderno, em relação à forma como se dá a construção do herói correlacional. Ou seja, para criar a identidade heroica o poeta agrega à imagem do herói várias imagens de heróis famosos no universo cultural, tais como o guerreiro São Miguel Arcanjo, o herói grego Hércules, o líder bíblico Moisés, o Rei Augusto, e até o Demônio, por exemplo. O poeta, no ato de criação, faz uma superposição desses heróis para construir a imagem de seu Sepé, um morubixaba rebelde, mescla de santo e demônio. Esse recurso cria o herói correlacional.

Quanto a forma que o herói se apresenta no épico, temos um heroísmo mítico individual, centralizada na figura lendária do Sepé Tiaraj, chefe e inconfundível líder da Taba:

De São Miguel intrépido bagual,

De força hercúlea sobrenatural,

Herdeiro da nobreza dos antanhos,

A cavalgar os sôfregos corcéis,

Te entregavas às lutas sem quartéis,

Contra os ladrões de glebas e rebanhos.

(FERNANDES BARBOSA, 1964, p. 12)

Outra característica que realça o protagonismo heroico do índio é o seu discurso, destacado pelo autor para dar ênfase à voz do índio, que aparece pouco em O Uraguai (1769), de Basílio da Gama. Vejamos um trecho que o índio recusa à vassalagem e servidão colonial:

Ao te pedirem que boleasse a perna,

Para beijar, num gesto de consterna,

A mão do general com devoção,

Respondeste ao intérprete crinudo:

- Por que beijar a mão do botocudo,

Invasor do meu lar, do meu torrão?!

\section{- O exército espanhol voltou em paz}

E espero que daqui também te vás,

Levando suas armas imperiais.

- Ao índio diga que ele é um selvagem!

E Sepé desprezando a vassalagem:

- Diga-lhe que sim, e êle muito mais!

(FERNANDES BARBOSA, 1964, p.32 - grifo do poeta) 
Em relação ao percurso heroico, o índio transita do plano histórico para o maravilhoso, quando incorpora a identidade dos vários heróis, aqui já citados. Dentre eles, os principais são os heróis da fé Moisés e Jesus Cristo da tradição Judaico-cristã. A terra indígena é comparada ‘a Canãa, Terra Prometida aos hebreus, terra da fartura, que manava leite e mel. Diferente do herói bíblico, Moisés que teve a missão libertar o povo de Israel da Terra do Egito e da escravidão de Faraó e levar o povo de Deus à terra prometida, o índio se ve na missão de levar seu povo à escravidão e/ou expulsão das suas terras, com a execução do Tratado de Madri. Vejamos abaixo um fragmento:

Ao passo que a Colônia lusitana, Que despertara a gula castelhana,

E à esquerda do Prata as águas fita,

Não poderia nunca interessar

A Sepé que teria que emigrar,

Como Moisés e o povo israelita.

(FERNANDES BARBOSA, 1964, p. 21)

O índio assim como Moisés era gago e legislador, mas, como vimos no poema Sepé parece demonstrar um discurso racional e fluente, além de um lutador para fazer valer os direitos de seu povo, como canta o eu-lírico:

Corregedor sem manchas e sem medo,

Levaste à cara dos mandões o dedo,

Sem temer a presilha dos arrochos,

Dizendo alto ao general do trono,

Que esta terra, em verdade, tinha dono,

Exímio domador de queixos rochos.

Cadê, meu Deus, os sóbrios Tribunais,

Onde Sepé pudesse gritar mais,

Contra o cruel Tratado desumano?!

Mas o real mandado de despejo

Era de Judas o tisnado beijo,

Para mostrar do pago soberano.

(FERNANDES FERNANDES BARBOSA, 1964, p. 25)

A aderência mítica principal, ocorre quando o índio é comparado à imagem de Jesus Cristo, que se torna o ponto de exaltação máxima da figura do índio, que assim como o Messias enfrentou o seu calvário pela causa do povo: 
Se julgavam-te as Côrtes índio guaxo,

Demonstraste em seguida que eras macho,

Inconfundível guasca do torrão,

Que soube erguer no topo do Calvário,

Nosso primeiro grito tumultuário,

Comandando a primeira rebelião.

(FERNANDES BARBOSA, 1964, p.27)

Mais adiante ele cita a condenação do índio Sepé à Cruz, pelos padres Jesuítas e pelos colonizadores, tal como Jesus que foi condenado por políticos e religiosos de seu tempo:

Teus santos eram bons e milagrosos,

Mas deles se esqueceram os poderosos,

Te condenaram ao peso dessa cruz,

E pondo à calva as garras miseráveis,

Talvez aquelas mãos abomináveis,

Que ergueram troncos pra surrar Jesus.

(FERNANDES BARBOSA, 1964, p. 49)

Quanto à ação heroica, o que marca a transição do herói do plano mítico para o maravilhoso, e o consagra como herói épico, são os feitos redentores que ele faz durante sua jornada épica na tentativa de defender as terras indígenas dos invasores coloniais. Vejamos abaixo aparição do índio após, três dias de morto, enfrentar seu Calvário e condenado a uma cruz simbólica, pois morreu lutando e recebendo um lançaço às costas, pelo "Satanás dragão", o Joaquim Viana, Governador de Montevidéu, e vanguardeiro do exército espanhol:

No céu do pago teu lunar brilhando,

Parece até que aos índios apontando,

Mostra o caminho exato do dever,

E pela voz de enúbias que retinam,

Agora todos eles se aglutinam,

No derradeiro anseio de vencer,

Inda tem dono a terra missioneira:

É Languiru que toma da bandeira,

Do sonho libertário de Sepé,

Da qual à sombra leva, a descoberto, 
Os índios pra chacina que vem perto,

Da batalha imortal do Caibaté.

De luto já três dias são passados,

Quando abatidos e desarvorados,

Num pôr de sol de dor e de saudade,

Os índios descem pelos descampados,

E de Castela caem sôbre os soldados,

Num delírio final de liberdade.

(FERNANDES BARBOSA, 1964, p. 71-72)

Temos a aparição do índio Sepé, no céu "indicando o caminho exato do dever", de morrer lutando pela causa edificante. Lembrando quando Cristo apareceu a seus discípulos, três dias após de morto, em ressurreição, ordenando: "Ide por todo mundo e pregai o evangelho". Diferente dos discípulos de Cristo, os índios resistem lutando a ter que deixar a sua terra, mas semelhante aos seguidores do Messias são fiéis à ordem do líder. No épico, o canto termina com Languiru "levando os índios ao suicídio", que teve como consequência a chacina de mil e quinhentos guaranis.

\section{CoNSIDERAÇõES FinaIS}

Sepé, o morubixaba rebelde é o que Genette (2010) chama de obra palimpsesta ou uma escrita de segunda mão. Já que a primeira obra O Uraguai, foi raspada para criação de uma nova. Podendo, no entanto, ler-se a antiga sobre a nova.

Entendido assim, como uma escrita de segunda mão, ou um palimpsesto, Sepé - o morubixaba rebelde não seria escrito dessa forma contestadora, se não existisse O Uraguai, de Basílio da Gama. Percebe-se aí uma relação de dependência textual, em que a leitura prévia do poema de Basílio da Gama é um requisito para compreensão plena do poema de Fernandes Barbosa, o que não significa dizer que ambas não podem ser lidas isoladamente. Ao contrário, as duas obras têm qualidades artísticas ímpares e individualizadas, e expressam bem a filosofia, ideologia e visão artística de seu tempo. Só que a leitura de ambas, de forma dialógica, enriquece o senso crítico e a compreensão sobre a visão artística dos autores sobre o herói Sepé.

A reescrita da história heroica de Sepé Tiaraju faz considerar que ocorre um processo de transformação do texto $\mathrm{A}$ no texto $\mathrm{B}$, isto é, ocorre emulação. Pois trata de uma reescrita que preza pela diferença, não somente a semelhança. Temos aí a mimese não somente pela imitação, mas pela emulação. Uma vez que, ao mesmo tempo em que, Fernandes Barbosa reescreve a história, criando um novo canto épico para valorização do índio Sepé Tiaraju. 


\section{REFERÊNCIAS}

BIBLIOGRAFIA LITERÁRIA

FERNANDES BARBOSA, N. Sepé, o morubixaba rebelde. Porto Alegre - RS: Tipografia Santo Antônio - Pão dos pobres, 1964.

LOPES NETO, S. São Sepé. In. Contos Gauchescos \& Lendas do Sul. Porto Alegre-RS: L\&PM, 1998, p.227-234.

\section{BIBLIOGRAFIA TEÓRICO-CRÍTICA}

ACCIOLY, M. Latinomérica. Rio de Janeiro: Topbooks, 2001.

ANDERSON, B. R. Comunidades Imaginadas: reflexões sobre a origem e a difusão do nacionalismo. São Paulo: Companhia das Letras, 2008.

ARRUDA, P. H. de M. As Reformas Pombalinas na Universidade de Coimbra: algumas considerações. PUCRJ: IX Congresso Nacional de Educação - EDUCARE, III Encontro Sul Brasileiro de Psicopedagogia. 26 a 29 de out. 2009.

BAKHTIN, M. Problemas da Poética de Dostoiévski. Rio de Janeiro: Forense Universitária, 1981. BAKHTIN, M. A Cultura Popular na Idade Média e no Renascimento: o contexto de François Rabelais. São Paulo/Brasília: Hucitec/UnB, 1993.

BAKHTIN, M. Estética da criação verbal. São Paulo: Martins Fontes, 1997.

BAKHTIN, M. Epos e romance: sobre a metodologia do estudo do romance. In: Questões de literatura e de estética: a teoria do romance. Trad. Aurora F. Bernardini et al. 4. ed. São Paulo: Editora UNESP, 1998. p. 397-428.

BAKHTIN, M. Marxismo e filosofia da linguagem. 12. ed. São Paulo: HUCITEC, 2006.

BRANDÃO, R. de O. A poética Clássica: Aristóteles, Horácio, Longuino. Trad. BRUNA, Jaime. 12 ed. São Paulo: Cultrix, 2005.

CANDIDO, A. Na sala de aula: caderno de análise literária. 9.ed. Editora Ática, 1984.

CANDIDO, A. Iniciação à Literatura Brasileira. São Paulo: Humanitas Publicações - FFLCH/ USP,1999.

CANDIDO, A. Literatura e Sociedade. 9. ed. Rio de Janeiro: Ouro sobre Azul, $2006 \mathrm{a}$.

CANDIDO, A. Formação da literatura brasileira: momentos decisivos, 1750-1880. 10. ed. Rio de Janeiro: Ouro sobre Azul, 2006b.

CARVALHAL, T. F. Literatura Comparada. 4. ed. rev. e ampliada. São Paulo: Ática, 2006. COUTINHO, A. A literatura no Brasil. Rio de Janeiro, José Olympio, 1986.

DERRIDA, J. Posições. Tradução de Tadeu da Silva. Belo Horizonte: Autêntica, 2001. 
FOUCAULT, M. A Ordem do Discurso. Trad. Laura Fraga de Almeida Sampaio. 3. ed. São Paulo: Edições Loyola, 1996.

GAGNEBIN, J. M. Verdade e memória do passado. In: Lembrar, Escrever, Esquecer. São Paulo: Editora 34, 2006.

GEERTZ, C. A interpretação das Culturas. 1. ed. 13 reimp. Rio de Janeiro: LTC, 2008, p. 04.

GENETTE, G. Palimpsestos: a literatura de segunda mão. Tradução de Cibele Braga et al. Belo Horizonte: Edições Viva Voz, 2010.

HALL, S. A identidade cultural na pós-modernidade. 6.ed. Rio de Janeiro: DP\&A,2001.

JAUSS, H. R. A estética da recepção: colocações gerais. In: LIMA, L. C. (Coord., sel., notas). A literatura e o leitor: textos de estética da recepção. 2. ed. Rio de Janeiro: Paz e Terra, 2002.

KRISTEVA, J. Introdução à Semanálise. São Paulo: Perspectiva, 1974.

LIMA, L. C. Sociedade e discurso ficcional. Rio de Janeiro: Guanabara, 1986.

LIMA, L. C. O Fingidor e o Censo: no Ancié Régi me, no Iluminismo e hoje. Rio de Janeiro: Forence Universitária, 1988.

LIMA, L. C. $\mathbf{O}$ controle do imaginário: razão e imaginação nos tempos modernos. 2 ed. ver. ampl. Rio de Janeiro: Forence Universitária, 1989.

LUGON, C. A república Comunista Cristã dos Guaranis (1610-1768). Tradução de Álvaro Cabral. Rio de Janeiro-RJ: Editora Paz e Terra LTDA, 1968.

MASSAUD, M. Dicionário de termos literários. Cultrix, São Paulo, 2004.

MILNER, A. Estudos Culturais. In: WILLIAMS, R. Palavras-chave: um vocabulário de cultura e sociedade. São Paulo: Boitempo, 2007, p. 420-27.

NEIVA, S. Avatares da epopeia na poesia brasileira do final do século XX. Recife: Fundação Joaquim Nabuco, 2009.

NEJAR, C. Arcádia e os poetas mineiros no século XVIII - Manuel Inácio da Silva Alvarenga. In: História da Literatura Brasileira: da carta de Caminha aos Contemporâneos. São Paulo: Leya, 2011, p. 77-8.

NITRINI, S. Literatura Comparada: história, teoria e crítica. 3. ed. São Paulo: EdUSP, 2010.

NUNES, C. T. da F. de M. A Universidade de Coimbra e a Reforma Pombalina de 1972. São Cristóvão: Editora UFS, 2013.

NUNES, R. A. Nas sombras da Libertinagem: Francisco de Melo Franco (1757-1822) Entre Luzes e censura no mundo Luso-Brasileiro. Niterói, Dissertação de Mestrado em História da UFF, 2011.

OLIVEIRA, L. E. (org.). A legislação pombalina sobre o ensino de línguas: suas implicações na educação brasileira (1757-1827). Maceió: EDUFAL, 2010. 
PERRONE-MOISÉS, L. Vira e mexe nacionalismo: paradoxos de nacionalismo literário. São Paulo: Companhia das Letras: 2007.

PROENÇA FILHO, D. José Basílio da Gama. In. Roteiro da poesia brasileira: Arcadismo. São Paulo: Global, 2006.

RAMALHO, C. Vozes Épicas: história e mito segundo as mulheres. Rio de Janeiro: Tese de doutorado da UFRJ, 2004.

RAMALHO, C. Poemas Épicos: estratégias de leitura. Rio de Janeiro: Uapê, 2013.

ROUSSEAU, J-J. O Contrato Social: Princípios do diretório político. Trad. Antônio de Pádua Danesi. São Paulo: Martins Fontes, 1999.

SANTOS, S. G. dos. Sepé Tiaraju, herói literário: Figurações da identidade. Dissertação de Mestrado em Letras. Santa Maria, RS: UFSM, 2006.

SILVA, A. V. da; RAMALHO, C. História da Epopéia Brasileira: teoria, crítica e percurso. Vol-1. Rio de Janeiro: Garamond, 2007.

SILVA, A. V. da; RAMALHO, C. História da Epopéia Brasileira: da origem ao século XVIII. Vol-2. Aracaju: Artner, 2015.

SILVA, J. N. de S. Obras Poéticas de Manoel Ignacio da Silva Alvarenga (Alcindo Palmireno) colegiadas, anotadas e precedidas de juízo crítico dos escritores nacionais e estrangeiros e de uma notícia sobre o autor e suas obras e acompanhadas de documentos históricos por Joaquim Norberto de Souza Silva. Tomo 1. Rio de Janeiro: Livraria B. L. Garnier, 1864.

SOETHE, P. A. Literatura e mimese. In: Literatura Comparada. Curitiba: IESD Brasil S.A, 2009. SOUZA, L. M. T. M. de. Hibridismo e tradução cultural em Bhabha. In: JÚNIOR, B. A. Margens da Cultura - Mestiçagem, Hibridismo e outras misturas. São Paulo: Boitempo, 2004.

TAVARES, H. Teoria Literária. Belo Horizonte: Itatiaia, 2002.

TeIXeIrA, I. Mecenato Pombalino e Poesia Neoclássica: Basílio da Gama e a Poética do encômio. São Paulo: Editora da Universidade de São Paulo, 1999.

\section{DisSERTAÇÃo}

OLIVEIRA, E. dos S. O herói Sepé em duas versões: O Uraguai e Sepé - o morubixaba rebelde. Dissertação de Mestrado. São Cristóvão-SE: Universidade Federal de Sergipe-UFS, 2016.

\section{ARTIGOS DE JORNAIS}

AZEVEDO JR., J. L. B. Aplausos a um poeta. In: Jornal do Povo. Cachoeira do Sul - Rio Grande do Sul, 1964. 
AZEVEDO JR., J. L. B. - Modernismo é um retrato do túneo: só se enxerga o oco. In: Jornal do Povo,1981.

GAMA DE BEM, Belchior. Letras da cidade em 1964. In. Jornal do Povo. Cachoeira do Sul - Rio Grande do Sul, 1965.

MACHADO, F. G. Carta ao poeta Fernandes Barbosa. In: Jornal do Povo.

SARAIVA DE ALMEIDA, N. S. E morrera Fernandes Barbosa! In: Jornal do Povo. Cachoeira do Sul - Rio Grande do Sul, 1988.

PALESTRAS E CONFERÊNCIAS EM VÍDEO:

NEIVA, S. Tensões em torno da poesia épica na modernidade. Palestra proferida no $10^{\circ}$ Ciclo de Conferências: A Epopeia Revitalizada. Rio de Janeiro, 2012. Último acesso em julho de 2014. Disponível em: <https://www.youtube.com/watch?v=eazuynYLN8s>.

SILVA, A. V. da. Épicos brasileiros da contemporaneidade. Palestra proferida no $10^{\circ}$ Ciclo de Conferências: A Epopeia Revitalizada. Rio de Janeiro, 2012. Último acesso em setembro de 2014. Disponível em: < http://www.youtube.com/watch?v=CKvcfQBVHB4 >.

Recebido para publicação em 19 dez. 2018. Aceito para publicação em 30 jul. 2019. 


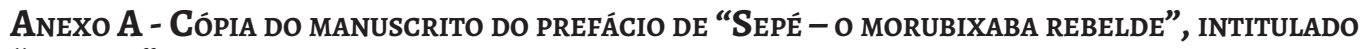
"PÓRTICO" FEITO PELO ESCRITOR MANOELITO DE ORNELLAS. ${ }^{7}$

O Poema de Pernandes Barbosa

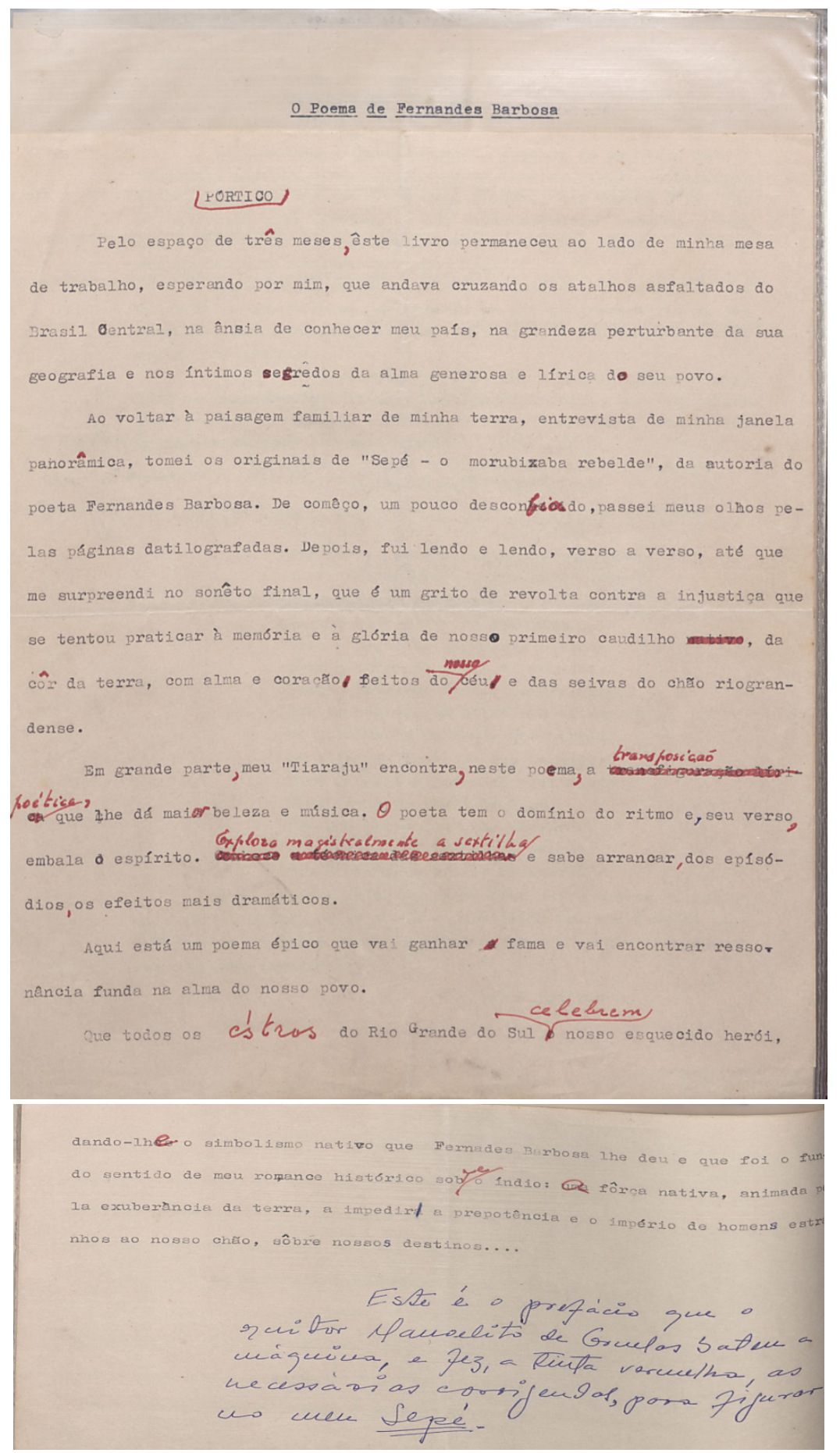

${ }^{7}$ A versão original encontra-se no Museu Municipal Edyr Lima, em Cachoeira do Sul - Rio Grande do Sul. Tive acesso em $08-2015$.

Uniletras, Ponta Grossa, v. 40, n. 1, p. 135-156, jan/jun. 2018 Disponível em: <http://www.revistas2.uepg.br/index.php/uniletras> 


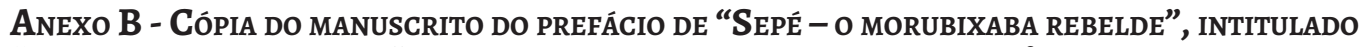
“CONVERSA DESNECESSÁRIA" FEITO PELO HISTORIADOR WALTER SPALDING. ${ }^{8}$

\section{CONVERSA DESAECESSARIA.}

A época presente, para quem, como nós, já ultrapassou os sessenta, é tôda de desencanto, materialmente falando. E às vêzes também intelectualmento. Sentimo-nos como numa encmuzithada de três bôcas, acampados num ranchito sem saber que fazer. I temos a nf́tida intuicão de wk estamos sobrando no mundo.

Entretanto, de quando om quando, um sol diferente bate à nossa porta e penetra na humildade esquecida de nosso rancho. Um solzito amigo min nos ver dizer que nem tudo está perdido. Que ainda há alma, th ainda há sentimento, sul ainda há patriotismo, NM ainda se estuda, se pensa e se medita por estas encruzithadas modernas que cruzam, e recruzam nossa terra. Ainda aparecem, para nos iluminar a vidatuclicus indo, eseritores e poetas wh heckm raizes bem cravadas na terra maravilhosa de nosso nago.

E foi justamente num momento de maior desalento, me custaute om que, por todos os lados a demagogia, a incompreensão a a mentira ostentam aos ventos gaúchos suas bandeiras nefastas, que recebemos, pelo correio, um pacotinho com os originais de nôvo poema de Fernandes Barbosa: SEPF-O MORUBTXABA REBELDE.

Ontem, em momento azado, êste delicado e delicioso poeta nos mandara os originais de SUPLIEA AO NEGRTNHO DO PASTORETO, que depois publicou, $\theta$ que é, na realidade, un dos mais belos poemas ao lendário Negrinho amigo.

Hoje, SEPÉ-O MORUBIXABA REBEIDE, un canto de glória ao Rio Grande do pas sado, ao veIho Rio Grande semi-espanhol por que dirigido pelos jesuítas sob a bandeira de Espanha. Mas nosso sempre, pela continuidade de terra, pelo amor de nossa gente àqueles tratos misstoneiros, que legou à nossa história, como primeiro homem de sentir teIúrico - Kur fall SEPE TIARAJU, - o sanluisen-

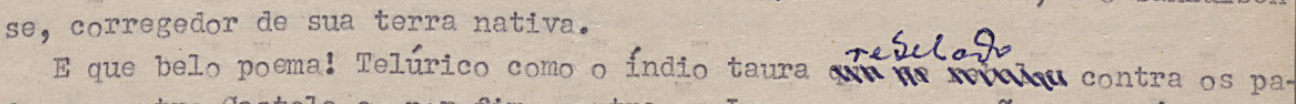
dres, contra Castela e, por fim, contra os Lusos por injunços da própria. marcha dos acontecimentos de então.

Fermandes Barbosa deu-nos, assim, um poema heróico consagrando a figura invulgar do índio intrépido que preferiu a morte à escravidão, daquelo "São Jorge om cerne das Missões", conforme o proclama o grande poeta Aureliano de Tigueiredo Pinto (Romances de Estância e Querência - II - Amorial de Estância e outros poomas - I963), om versos candentes a cantantes, ambos.

Sepé está redivivo no poema de Fernandes Barbosa, cue, fascinadoramente,

\footnotetext{
${ }^{8}$ A versão original encontra-se no Museu Municipal Edyr Lima, em Cachoeira do Sul - Rio Grande do Sul. Tive acesso em $08-2015$.
} 